\title{
Arachnomelia in Brown Swiss cattle maps to chromosome 5
}

\author{
Cord Drögemüller · Marco Rossi · Arcangelo Gentile $\cdot$ Stefania Testoni · \\ Hannes Jörg · Gerald Stranzinger · Michaela Drögemüller · \\ Marie-Louise Glowatzki-Mullis · Tosso Leeb
}

Received: 12 September 2008/ Accepted: 12 November 2008/Published online: 31 December 2008

(C) Springer Science+Business Media, LLC 2008

\begin{abstract}
Arachnomelia in Brown Swiss cattle is a monogenic autosomal recessive inherited congenital disorder of the skeletal system giving affected calves a spidery look (OMIA ID 000059). Over a period of 20 years 15 cases were sampled in the Swiss and Italian Brown cattle population. Pedigree data revealed that all affected individuals trace back to a single acknowledged carrier founder sire. A genome scan using 240 microsatellites spanning the 29 bovine autosomes showed homozygosity at three adjacent microsatellite markers on bovine $\mathrm{Chr} 5$ in all cases. Linkage analysis confirmed the localization of the arachnomelia mutation in the region of the marker ETH1O. Finemapping and haplotype analysis using a total of 34 markers in this region refined the critical region of the arachnomelia locus to a 7.19-Mb interval on bovine $\mathrm{Chr} 5$. The diseaseassociated IBD haplotype was shared by 36 proven carrier animals and allows marker-assisted selection. As the
\end{abstract}

Electronic supplementary material The online version of this article (doi:10.1007/s00335-008-9157-2) contains supplementary material, which is available to authorized users.

C. Drögemüller $(\bowtie) \cdot$ M. Drögemüller .

M.-L. Glowatzki-Mullis · T. Leeb

Institute of Genetics, Vetsuisse Faculty, University of Berne,

Bremgartenstrasse 109a, 3001 Berne, Switzerland

e-mail: cord.droegemueller@itz.unibe.ch

M. Rossi - A. Gentile

Veterinary Clinical Departement, University of Bologna,

Bologna, Italy

S. Testoni

Department of Veterinary Clinical Science, University

of Padova, Padova, Italy

H. Jörg · G. Stranzinger

Institute of Animal Sciences, ETH Zurich, Zurich, Switzerland corresponding human and mouse chromosome segments do not contain any clear functional candidate genes for this disorder, the mutation causing arachnomelia in the Brown Swiss cattle might help to identify an unknown gene in bone development.

\section{Introduction}

Inherited bovine arachnomelia, also termed syndrome of arachnomelia and arthrogryposis, is a congenital abnormality of the skeletal system giving affected calves a spidery look (spider-legs; OMIA ID 000059; Fig. 1). The bones of the legs appear to be more fragile than normal and spontaneous fracture during calving may injure the dam. Arachnomelia-affected calves are delivered full term and born dead or die soon after birth. The most important pathologic findings are facial deformities, bone dolichostenomelia, angular deformities in the distal part of the hind legs, muscular atrophy, and sometimes cardiac malformations (Testoni and Gentile 2004). In addition to single unrelated cases of arachnomelia-affected Holstein cattle, recessive inherited arachnomelia was initially reported in German Fleckvieh cattle (Rieck and Schade 1975). Recently, more than 140 cases of arachnomelia-affected calves were reported in the Bavarian Simmental population which all traced back to a single founder (Buitkamp et al. 2008). An outbreak of arachnomelia in the European Brown cattle population occurred during the $1980 \mathrm{~s}$ after the improvement of the local Brown cattle breeds by extensive usage of highly selected American Brown Swiss sires (Brem et al. 1984; König et al. 1987; Lidauer and Essl 1994). There is no relationship between the putative founder animals that introduced the arachnomelia mutation 


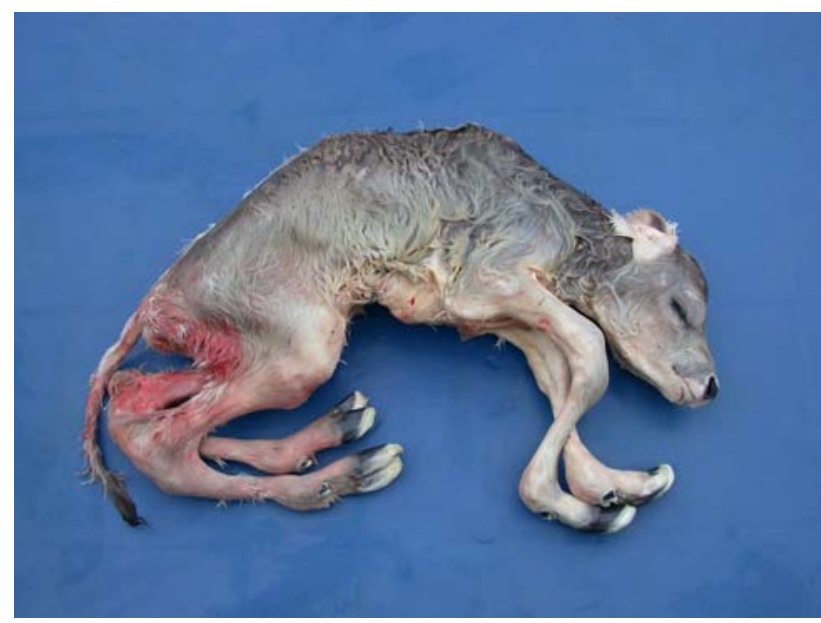

Fig. 1 Arachnomelia in a Brown Swiss calf

in Simmental and Brown Swiss cattle, respectively. Arachnomelia (A) in Brown Swiss follows an autosomal monogenic recessive inheritance with full penetrance, and a control breeding program based on the identification of heterozygous carriers by pedigree analyses was established in Switzerland in 1985 (König et al. 1987). However, there are still A-carriers within the international Brown Swiss cattle population. Recently, four cases of arachnomelia were reported from Italy (Testoni and Gentile 2004). Initially, it seemed that the pathogenesis of bovine arachnomelia resembled that of human Marfan syndrome (Rieck and Schade 1975). However, recent clinical findings recorded in arachnomelia-affected calves differ from the typical picture of human Marfan patients (Testoni and Gentile 2004). Moreover, a different phenotype, more closely resembling human Marfan syndrome, has recently been described in cattle harboring a disease-causing mutation in the bovine FBN1 gene (Singleton et al. 2005).

The aim of this study was to localize the genetic locus responsible for arachnomelia in Brown Swiss cattle. We therefore performed a microsatellite-based genome scan and subsequently fine-mapped the linked chromosome region by analysis of additional markers from the bovine genome sequence combined with haplotype analysis and the identification of recombinant chromosomes.

\section{Material and methods}

Animals

A total of 15 calves ( 7 females, 8 males) with the clinical and pathologic diagnosis of arachnomelia and their available ancestors were sampled in the Brown Swiss cattle population of Italy and Switzerland between 1988 and 2007. A total of 36 acknowledged A-carriers, classified as obligate heterozygotes, that have recorded arachnomelia offspring and are related to the assumed founder of the established family were collected (Fig. 2). In addition, samples of 13 progeny-tested noncarrier sires related to the founder sire of the family were available. Genomic DNA was obtained from blood, semen, or tissue using the DNeasy Blood \& Tissue Kit (Qiagen, Valencia, CA). The initial genome scan was performed using a subset of 8 affected and 19 A-carrier animals (Fig. 2). The subsequent fine-mapping studies were performed on the entire animal set.

\section{Microsatellite genotyping}

Two hundred forty microsatellite markers taken from the latest bovine genetic map were used for the genome scan (Ihara et al. 2004; Supplementary Table 1). The order of the markers and map distances were based on the cattle genome sequence (build 4.0). These 240 markers covered all 29 autosomes with an average spacing of $10.6 \mathrm{Mb}$. Microsatellite markers were amplified using the Multiplex PCR Kit (Qiagen) and fragment size analyses were determined on an ABI 3730 capillary sequencer (Applied

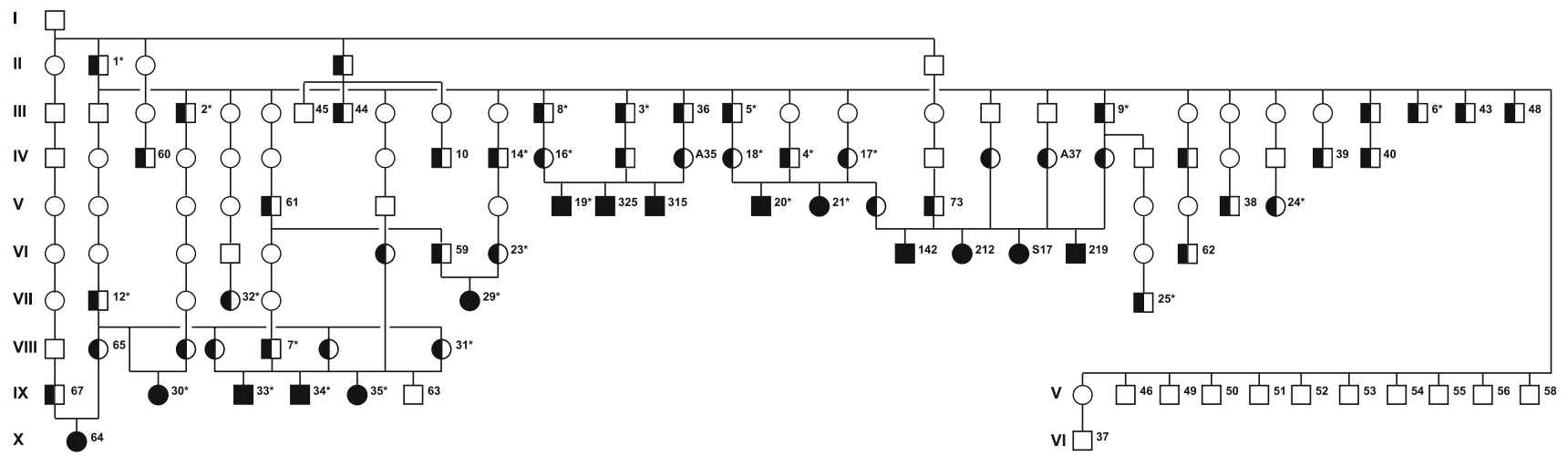

Fig. 2 Ten-generation pedigree of the Brown Swiss cattle family segregating for arachnomelia. Affected animals are filled symbols and obligate heterozygous animals are half-filled. Animals that were included in the genome scan are indicated with a star 
Table 1 Association analyses using $\chi^{2}$ tests for ten microsatellite markers and arachnomelia in Brown Swiss cattle

\begin{tabular}{|c|c|c|c|c|c|c|c|c|c|c|c|c|}
\hline \multirow[t]{2}{*}{ Marker } & \multirow[t]{2}{*}{ Chr } & \multirow[t]{2}{*}{ Genomic position $(\mathrm{Mb})$} & \multicolumn{2}{|c|}{ Controls } & \multicolumn{2}{|c|}{ Affecteds } & \multicolumn{3}{|c|}{$\chi^{2}$ tests for association } & \multicolumn{3}{|c|}{ Error probability } \\
\hline & & & $n$ & Alleles & $n$ & alleles & Genotype & Allele & Trend & Genotype & Allele & Trend \\
\hline BMS711 & 1 & 20.12 & 19 & 4 & 8 & 4 & 15.952 & 8.872 & 6.893 & 0.026 & 0.031 & 0.075 \\
\hline$D I K 4673$ & 2 & 62.9 & 18 & 6 & 7 & 3 & 12.316 & 13.948 & 11.335 & 0.264 & 0.016 & 0.045 \\
\hline RM500 & 5 & 51.91 & 19 & 3 & 8 & 1 & 2.584 & 2.320 & 2.584 & 0.108 & 0.128 & 0.108 \\
\hline$B R 2936$ & 5 & 56.35 & 19 & 4 & 8 & 1 & 10.556 & 7.209 & 10.556 & 0.014 & 0.066 & 0.014 \\
\hline ETH10 & 5 & 60.84 & 19 & 4 & 8 & 1 & 19.326 & 10.447 & 19.326 & 0.000 & 0.015 & 0.000 \\
\hline$D I K 4606$ & 7 & 35.12 & 19 & 6 & 7 & 5 & 12.870 & 11.942 & 9.259 & 0.379 & 0.036 & 0.099 \\
\hline ETH7 & 13 & 55.21 & 19 & 4 & 8 & 1 & 2.584 & 3.386 & 2.584 & 0.460 & 0.336 & 0.460 \\
\hline RM327 & 13 & 60.8 & 19 & 7 & 8 & 5 & 19.806 & 15.835 & 14.994 & 0.071 & 0.015 & 0.020 \\
\hline CSSM66 & 14 & 3.94 & 19 & 9 & 8 & 8 & 23.803 & 6.896 & 7.471 & 0.033 & 0.548 & 0.487 \\
\hline BMS462 & 16 & 73.87 & 19 & 4 & 8 & 1 & 0.798 & 0.766 & 0.798 & 0.671 & 0.682 & 0.671 \\
\hline
\end{tabular}

Biosystems, Foster City, CA) and analyzed with the GeneMapper 4.0 software (Applied Biosystems).

For fine-mapping, new microsatellite markers in the linked region of $\mathrm{Chr} 5$ were developed by Tandyman search (http://snp.lanl.gov/tandyman/cgi-bin/tandyman.cgi) using the bovine genome sequence (Supplementary Table 2). The sequences of the $\mathrm{Chr} 5$ markers were anchored to the human genome sequence (build 36) using BLASTN.

\section{Data analysis}

Correctness of Mendelian inheritance of markers was confirmed using Pedstats software (Wigginton and Abecasis 2005). The ALLELE procedure of the software package SAS/Genetics (ver. 9.1.3; SAS Institute Inc., Cary, NC) was used to calculate the number of alleles, the observed heterozygosity, and the polymorphism information content (PIC) of the markers. Preliminary association analyses were performed using the CASECONTROL procedure of SAS/Genetics, which tests for dominant allele effects on the disease penetrance, and the allele case-control test and the linear trend test, which test for additive allele effects on the disease penetrance. Multipoint parametric linkage analysis under the assumption of arachnomelia segregating as a biallelic autosomal recessive trait with complete penetrance was performed with Merlin software ver. 1.1.2 (Abecasis et al. 2002). A frequency of 0.01 was assumed for the mutated allele. The pedigree was split into two subpedigrees due to the high proportion of missing DNA samples. The LOD score test statistic was used to estimate the proportion of linked families $(\alpha)$ and the corresponding maximum heterogeneity LOD score. To reconstruct the most likely haplotypes and identify recombinations, we applied the "best" option of Merlin software and the Haplopainter software for visualization (Thiele and Nürnberg 2005).

\section{Results and discussion}

We compiled a pedigree of a Brown Swiss cattle family segregating for arachnomelia (A), which was consistent with monogenic autosomal recessive inheritance (Fig. 2). All 15 affected calves were inbred from a probable founder sire named Norvic Larry's LILASON, born in 1957. The founding mutation thus probably occurred four to nine generations before the cases occurred. The arachnomelia mutation was probably introduced by LILASON, as until now all acknowledged A-carriers can be traced back to this American Brown Swiss artificial insemination (AI) bull (Fig. 2). In particular, his son Norvic Lilason's BEAUTICIAN, born in 1960 (animal No. 1; Fig. 2), was earlier recognized as responsible for the worldwide diffusion of the defect in the Brown cattle breed (König et al. 1987). This popular AI sire disseminated the deleterious mutation, and inbreeding among the descendants increased the likelihood of arachnomelia emerging. After recognition of arachnomelia, frequencies of approximately $3 \%$ for the mutant A allele were estimated in the AI-derived Brown cattle populations of Switzerland and Austria (Fuschini et al. 1992; Lidauer and Essl 1994). As two proven Acarrier AI sires (Prealba Pete Rose AMARANTO and Superbrown Caod TOMMY-ET, animals No. 7 and 12; Fig. 2) of the current cases have been widely used in recent decades, further cases of the disease are expected. In light of the pedigree information, we hypothesized that the 15 arachnomelia-affected individuals of the established Brown Swiss cattle family would likely be homozygous for a common chromosome segment flanking the A locus. Therefore, we applied a homozygosity mapping approach to identify the genome region harboring the disease-causing mutation (Charlier et al. 1996, 2008).

We performed a microsatellite-based genome scan using 8 arachnomelia-affected calves and 19 proven carriers. The markers used for the whole-genome scan showed a mean 
Table 2 Disease-associated haplotypes (shaded columns) of 34 microsatellites of Chr 5 in 15 homozygous arachnomelia-affected calves and 36 heterozygous A-carriers

\begin{tabular}{|c|c|c|c|c|c|c|c|c|c|c|c|c|c|c|c|c|c|c|}
\hline \multirow[t]{2}{*}{ Marker } & \multirow{2}{*}{$\begin{array}{c}\text { Chr } 5 \\
(\mathrm{Mb})\end{array}$} & \multicolumn{10}{|c|}{ affected animals } & \multicolumn{7}{|c|}{ A-carriers } \\
\hline & & (4) & (2) & (2) & (1) & (1) & (1) & (1) & (1) & (1) & (1) & (21) & (5) & $(4)$ & (2) & (2) & (1) & (1) \\
\hline BMC1009 & 30.53 & & 280 & 280 & & & & & & & & 280 & 280 & & 280 & 280 & & \\
\hline$S A A 17$ & 39.09 & & 261 & 261 & & & & & & & & 261 & 261 & & 261 & 261 & & \\
\hline DIK4782 & 40.85 & & 168 & 168 & & & & & 168 & 168 & & 168 & 168 & & 168 & 168 & & \\
\hline SAA18 & 44.49 & & 167 & 167 & & & & & 167 & 167 & & 167 & 167 & & 167 & 167 & & \\
\hline SAA19 & 50.15 & 268 & 268 & 268 & 268 & & 268 & 268 & 268 & 268 & 268 & 268 & 268 & 268 & 268 & 268 & 268 & \\
\hline BMS 1617 & 51.89 & 164 & 164 & 164 & 164 & 164 & 164 & 164 & 164 & 164 & 164 & 164 & 164 & 164 & 164 & 164 & 164 & \\
\hline RM500 & 51.91 & 124 & 124 & 124 & 124 & 124 & 124 & 124 & 124 & 124 & 124 & 124 & 124 & 124 & 124 & 124 & 124 & \\
\hline DIK2732 & 55.83 & 205 & 205 & 205 & 205 & 205 & 205 & 205 & 205 & 205 & 205 & 205 & 205 & 205 & 205 & 205 & 205 & \\
\hline DIK2410 & 56.27 & 186 & 186 & 186 & 186 & 186 & 186 & 186 & 186 & 186 & 186 & 186 & 186 & 186 & 186 & 186 & 186 & \\
\hline BR2936 & 56.35 & 154 & 154 & 154 & 154 & 154 & 154 & 154 & 154 & 154 & 154 & 154 & 154 & 154 & 154 & 154 & 154 & \\
\hline$S A A 20$ & 56.74 & 112 & 112 & 112 & 112 & 112 & 112 & 112 & 112 & 112 & 112 & 112 & 112 & 112 & 112 & 112 & 112 & \\
\hline BMS490 & 57.29 & 181 & 181 & 181 & 181 & 181 & 181 & 181 & 181 & 181 & 181 & 181 & 181 & 181 & 181 & 181 & 181 & \\
\hline SAA21 & 58.14 & 205 & 205 & 205 & 205 & 205 & 205 & 205 & 205 & 205 & 205 & 205 & 205 & 205 & 205 & 205 & 205 & 205 \\
\hline$S A A 01$ & 58.21 & 180 & 180 & 180 & 180 & 180 & 180 & 180 & 180 & 180 & 180 & 180 & 180 & 180 & 180 & 180 & 180 & 180 \\
\hline SAA07 & 58.48 & 163 & 163 & 163 & 163 & 163 & 163 & 163 & 163 & 163 & 163 & 163 & 163 & 163 & 163 & 163 & 163 & 163 \\
\hline SAAO2 & 59.71 & 188 & 188 & 188 & 188 & 188 & 188 & 188 & 188 & 188 & 188 & 188 & 188 & 188 & 188 & 188 & 188 & 188 \\
\hline SAA03 & 60.53 & 236 & 236 & 236 & 236 & 236 & 236 & 236 & 236 & 236 & 236 & 236 & 236 & 236 & 236 & 236 & 236 & 236 \\
\hline ETH10 & 60.84 & 216 & 216 & 216 & 216 & 216 & 216 & 216 & 216 & 216 & 216 & 216 & 216 & 216 & 216 & 216 & 216 & 216 \\
\hline SAAO4 & 61.46 & 230 & 230 & 230 & 230 & 230 & 230 & 230 & 230 & 230 & 230 & 230 & 230 & 230 & 230 & 230 & 230 & 230 \\
\hline SAA05 & 61.87 & 149 & 149 & 149 & 149 & 149 & 149 & 149 & 149 & 149 & 149 & 149 & 149 & 149 & 149 & 149 & 149 & 149 \\
\hline AGLA254 & 63.99 & 194 & 194 & 194 & 194 & 194 & 194 & 194 & 194 & 194 & 194 & 194 & 194 & 194 & 194 & 194 & 194 & 194 \\
\hline$S A A 11$ & 64.09 & 189 & 189 & 189 & 189 & 189 & 189 & 189 & 189 & 189 & 189 & 189 & 189 & 189 & 189 & 189 & 189 & 189 \\
\hline$S A A 13$ & 64.48 & 226 & 226 & & 226 & 226 & 226 & 226 & 226 & & & 226 & 226 & 226 & 226 & 226 & 226 & 226 \\
\hline DIK5248 & 66.08 & 199 & 199 & & 199 & 199 & 199 & 199 & & & & 199 & 199 & 199 & 199 & 199 & 199 & 199 \\
\hline CSSM022 & 66.55 & 219 & 219 & & 219 & 219 & 219 & 219 & & & & 219 & 219 & 219 & 219 & 219 & 219 & 219 \\
\hline SAA16 & 67.40 & 221 & 221 & & 221 & 221 & 221 & 221 & & & & 221 & 221 & 221 & 221 & 221 & 221 & 221 \\
\hline$B M S 1216$ & 76.37 & 141 & 141 & & 141 & 141 & 141 & 141 & & & & 141 & 141 & 141 & 141 & 141 & 141 & 141 \\
\hline DIK5165 & 76.76 & 238 & 238 & & 238 & 238 & 238 & 238 & & & & 238 & 238 & 238 & 238 & & 238 & 238 \\
\hline RM029 & 80.42 & 82 & 82 & & 82 & 82 & 82 & 82 & & & & 82 & 82 & 82 & 82 & & 82 & 82 \\
\hline DIK545 & 88.27 & 127 & 127 & & 127 & 127 & 127 & & & & & 127 & 127 & 127 & & & 127 & 127 \\
\hline DIK 1048 & 90.42 & 122 & 122 & & 122 & 122 & 122 & & & & & 122 & 122 & 122 & & & 122 & 122 \\
\hline BMS 1248 & & 134 & 134 & & 134 & 134 & & & & & & 134 & 134 & 134 & & & & 134 \\
\hline DIK4329 & 96.03 & 201 & 201 & & 201 & 201 & & & & & & 201 & 201 & 201 & & & & 201 \\
\hline BM315 & 104.05 & 112 & & & & & & & & & & 112 & & & & & & 112 \\
\hline
\end{tabular}

Numbers in parentheses are the number of animals showing the specific haplotype. A block of ten perfectly associated markers representing the 7.19-Mb interval containing the A locus is framed

number of 5.3 alleles and an average polymorphism information content (PIC) of 0.57 (Supplementary Table 1). Therefore, they were supposed to be appropriate for disease gene mapping in our inbred family. Of 240 autosomal microsatellite markers tested, five were homozygous in all affected animals (Table 1). Three of these five markers, RM500, BR2936, and ETH10, were colocalized on the central part of bovine $\mathrm{Chr} 5$, and one of them $(E T H 10)$ was significantly associated $(p<0.01)$ with the arachnomelia phenotype (Table 1). The reduction of heterozygosity within the affected calves was complemented by the finding that the 19 genotyped carriers showed at least one copy of the allele, which was present in all eight cases at the three neighboring bovine $\mathrm{Chr} 5$ markers RM500, BR2936, and ETH10. Five additional markers were also associated with arachnomelia with $p<0.05$ (Table 1). However, as these five markers showed three to eight different alleles in the eight closely related cases and mapped to five different cattle chromosomes, they did not fit the hypothesis of a single chromosomal region of identity-by-descent (IBD) in all affected calves. To verify the results of the preliminary association study, we performed a linkage analysis that confirmed the localization of the A locus on bovine Chr 5. Markers with linkage in both subfamilies were observed only on Chr 5 . The highest LOD score of 1.11 was observed at marker ETH1O. No 


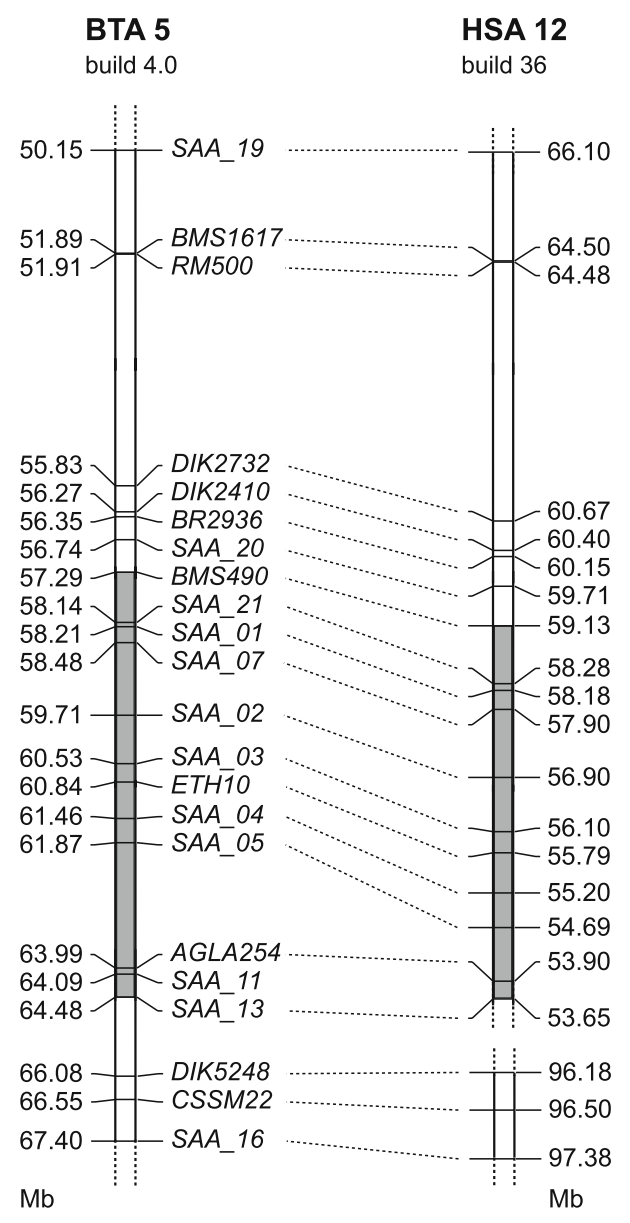

Fig. 3 Comparative map of bovine Chr 5 and human $\mathrm{Chr} 12$. The $\mathrm{Mb}$ positions of selected microsatellites of this study are indicated with respect to the bovine genome assembly (build 4.0). All markers were anchored by BLASTN searches on the human genome (build 36.3). The 7.19-Mb interval harboring the arachnomelia mutation is shaded

indication of significant linkage was detected on the other chromosomes (Supplementary Fig. 1).

Subsequently, we fine-mapped this region by examination of additional markers in extended-family material including 15 affected calves, 36 proven A-carriers, and 13 proven noncarriers (Fig. 2). We took 20 markers from the linkage map of bovine $\mathrm{Chr} 5$ and developed 14 new microsatellite markers from the bovine genome sequence. Parametric linkage analysis using the extended pedigree and additional markers confirmed the initial genome-wide results with a maximal LOD score of $9.21(\alpha=1)$ at marker $S A A 21$. We then calculated the most likely haplotypes at $34 \mathrm{Chr} 5$ microsatellites for all 64 available family members. All 15 affected calves were homozygous at 17 markers from BMS1617 to SAA11, which allowed the identification of a single disease-associated haplotype, narrowing the critical region to $14.3 \mathrm{Mb}$ between SAA19 and SAA13 (Table 2). Subsequently, we reconstructed the arachnomelia-associated haplotype for each obligate heterozygous animal. The previously established IBD haplotype was shared by 35 assumed A-carriers (Table 2), and 13 proven noncarriers received the entire wild-type haplotype from their A-carrying father or mother. One son of BEAUTICIAN (animal No. 6; Fig. 2), who sired at least two recorded arachnomelia-affected offspring, inherited a recombinant haplotype from his father. Thus, based on this single recombinant chromosome, the most likely position of the A locus on Chr 5 is between BMS490 as the centromeric boundary and $S A A 13$ as the telomeric boundary (Table 2). These markers flank a 7.19-Mb segment between positions 57.29 and $64.48 \mathrm{Mb}$ on $\mathrm{Chr} 5$ (build 4.0).

BLAST searches of the bovine markers with respect to the human genome (Supplementary Table 2) established a sequence-based framework for comparing the bovine and human genomes (Fig. 3). The bovine A-locus-containing interval corresponds to a syntenic $5.48-\mathrm{Mb}$ interval on human Chr 12 between 53.65 and $59.13 \mathrm{Mb}$. This human segment contains 127 genes, including a cluster of 29 olfactory receptor genes and 20 annotated hypothetical loci (build 36.3). These genes and also the information of the corresponding genes on the syntenic mouse $\mathrm{Chr} 10 \mathrm{seg}$ ment were screened for any known involvement in bone development. The human growth differentiation factor 11 gene (GDF11) resides at $54.42 \mathrm{Mb}$ on human $\mathrm{Chr} 12$ and is a member of the bone morphogenetic protein family and the TGF- $\beta$ superfamily, which are regulators of cell growth and differentiation in both embryonic and adult tissues. Gdf11-deficient embryos show anterior-posterior patterning defects and suggest that this protein is involved in mesodermal formation during embryonic development (McPherron et al. 1999). The resequencing of bovine GDF11 at $62.07 \mathrm{Mb}$ on bovine Chr 5 using DNA of affected and healthy Brown Swiss cattle revealed no sequence polymorphism within the three coding exons and flanking intron regions (data not shown). Further investigations into other genes in the region of interest did not suggest any other clear candidate genes. Therefore, either a noncoding mutation of the GDFI1 gene or a mutation in an as yet unknown bone development gene is probably responsible for arachnomelia in cattle.

In recent decades, outbreaks of four undesirable genetic defects (weaver disease, spinal dysmyelination, spinal muscular atrophy, arachnomelia) have occurred in Brown Swiss cattle (http://omia.angis.org.au). The arachnomelia disease is the only defect for which neither an indirect nor a direct DNA test to detect the carriers is available (Georges et al. 1993; Krebs et al. 2007; Nissen et al. 2001). Therefore, the established phase of Chr 5 marker alleles provides a set of flanking and closely linked markers for marker-assisted selection. In many cases, an indirect DNA test is reasonably accurate and gives a reliable indication of the disease 
genotype of an animal. In our case, the markers are linked to the disease-causing mutation, although in some cases, discussed below, they are not sufficiently specific for a diagnostic test. The linked marker alleles have a reduced association with the causative mutation as they occur also on nonmutant chromosomes. Both within the presented family and during our on-going genetic testings we identified some A-carriers that shared two copies of the disease-associated haplotype. The marker genotypes of these animals look completely homozygous, exactly as in arachnomelia-affected calves. For example, the bull TOMMY (animal No. 12; Fig. 2) is homozygous at 28 markers from SAA19 to BMS1248, covering about $40 \mathrm{Mb}$ of $\mathrm{Chr} 5$, and the bull $D I Q U$ (animal No. 73; Fig. 2) is homozygous at 19 markers from $S A A 18$ to $S A A 11$, covering about $30 \mathrm{Mb}$ of $\mathrm{Chr} 5$. A possible explanation is apparent from the pedigree of these animals, because both bulls are inbred to the father of the founder sire of our family presented in Fig. 2 (Supplementary Fig. 2). They probably got the disease-associated haplotype from the assumed arachnomelia founder LILA$S O N$ and the second haplotype without the A mutation was transmitted independently through several generations from the father of the founder (Supplementary Fig. 2). Experimental evidence for this segregation pattern was provided by genotyping the respective markers in three available male ancestors of TOMMY. These progeny-tested and widely used AI bulls were not registered as carriers of the arachnomelia mutation, but reconstruction of their haplotypes revealed the presence of the A-associated haplotype seen in affected calves. We think that these observations might explain the homozygosity of arachnomelia-linked $\mathrm{Chr} 5$ markers in unaffected cattle. According to this hypothesis, the mutation occurred on a common haplotype that was spread into the Brown Swiss breed by Lee's Hill MASTERPIECE, the father of LILASON. This name can be found in numerous pedigrees of highly frequented AI bulls. These findings make it possible to exactly date the causal mutation event, which must have occurred during the spermiogenesis of MASTERPIECE or during the early embryonic development of LILASON. The relatively young age of the mutation is also consistent with the extended homozygosity in the examined arachnomelia-affected calves as only a small number of recombination events have shortened the ancestral wild-type haplotype during four to nine meioses.

Genome-wide association analysis using whole-genome single nucleotide polymorphism (SNP) arrays is now emerging as a powerful method for high-resolution mapping of loci controlling phenotypic traits in domestic animals (Andersson 2008). In a recent proof-of-principle study, Charlier et al. (2008) have used this approach to identify the mutations underlying three monogenic recessive inherited diseases in cattle. A targeted genotyping of Chr 5 SNPs might help to slightly reduce the critical interval of the arachnomelia mutation by fine-mapping recombination events. Furthermore, SNPs may be used for improvement of indirect DNA testing once heterozygous markers are detected in carriers that are homozygous for the microsatellites. Progression from an indirect DNA test to a direct DNA test will require further research. It is difficult to predict the effort required to make this progression because of the high number of positional candidate genes within the identified 7.19-Mb region. The identification of the causative gene may reveal new insights into fundamental processes of bone differentiation. Therefore, the bovine arachnomelia phenotype represents an excellent naturally occurring model showing a complex developmental defect that can possibly be explored for a better understanding of similar defects in humans.

Acknowledgments We thank Oskar Grüter and the Schweizer Braunviehzuchtverband, Zug, for invaluable help in collecting samples and pedigrees and financial support. André Eggen, INRA, is acknowledged for providing a BAC clone. The authors thank Swissgenetics, Zollikofen, for providing data and semen samples. The Associazione Nazionale Allevatori Razza Bruna Italiana, Bussolengo, is acknowledged for collecting samples and providing data.

\section{References}

Abecasis GR, Cherny SS, Cookson WO, Cardon LR (2002) Merlinrapid analysis of dense genetic maps using sparse gene flow trees. Nat Genet 30:97-101

Andersson L (2008) Genome-wide association analysis in domestic animals: a powerful approach for genetic dissection of trait loci. Genetika (in press). doi:10.1007/s10709-008-9312-4

Brem G, Wanke R, Hondele J, Dahme E (1984) Occurrence of the arachnomelia syndrome in Bavarian Brown-Swiss x Braunvieh breed population. Berl Münch Tierärztl Wochenschr 97:393-397 (in German)

Buitkamp J, Luntz B, Emmerling R, Reichenbach HD, Weppert M, Schade B, Meier N, Götz KU (2008) Syndrome of arachnomelia in Simmental cattle. BMC Vet Res 4:39

Charlier C, Farnir F, Berzi P, Vanmanshoven P, Brouwers B, Vromans H, Georges M (1996) Identity-by-descent mapping of recessive traits in livestock: application to map the bovine syndactyly locus to chromosome 15 . Genome Res 6:580-589

Charlier C, Coppieters W, Rollin F, Desmecht D, Agerholm JS, Cambisano N, Carta E, Dardano S, Dive M, Fasquelle C, Frennet JC, Hanset R, Hubin X, Jorgensen C, Karim L, Kent M, Harvey K, Pearce BR, Simon P, Tama N, Nie H, Vandeputte S, Lien S, Longeri M, Fredholm M, Harvey RJ, Georges M (2008) Highly effective SNP-based association mapping and management of recessive defects in livestock. Nat Genet 40:449-454

Fuschini E, Fries R, Stocker H (1992) Missbildungen und Erbfehler beim Rind: Erfassung, Häufigkeiten und Bekämpfung der Erbfehler beim Braunvieh im Rahmen der Besamungszucht in der Schweiz. Wien Tierärztl Mschr 79:161-165

Georges M, Dietz AB, Mishra A, Nielsen D, Sargeant LS, Sorensen A, Steele MR, Zhao X, Leipold H, Womack JE, Lathrop M (1993) Microsatellite mapping of the gene causing weaver disease in cattle will allow the study of an associated quantitative trait locus. Proc Natl Acad Sci USA 90:1058-1062 
Ihara N, Takasuga A, Mizoshita K, Takeda H, Sugimoto M, Mizoguchi Y, Hirano $\mathrm{T}$, Itoh $\mathrm{T}$, Watanabe $\mathrm{T}$, Reed $\mathrm{KM}$, Snelling WM, Kappes SM, Beattie CW, Bennett GL, Sugimoto Y (2004) A comprehensive genetic map of the cattle genome based on 3802 microsatellites. Genome Res 14:1987-1998

König H, Gaillard C, Chavaz J, Hunziker F, Tontis A (1987) Prüfung von Schweizer Braunvieh-Bullen auf das vererbte Syndrom der Arachnomelie und Arthrogrypose (SAA) durch Untersuchung der Nachkommen im Fetalstadium. Tierärztl Umsch 42:692-697

Krebs S, Medugorac I, Röther S, Strässer K, Förster M (2007) A missense mutation in the 3-ketodihydrosphingosine reductase FVT1 as candidate causal mutation for bovine spinal muscular atrophy. Proc Natl Acad Sci USA 104:6746-6751

Lidauer M, Essl A (1994) Schätzung der Frequenzen rezessiver Letalgene für spinale Muskelatrophie, Spinnengliedrigkeit und Weaver-Syndrom beim österreichischen Braunvieh. Züchtungskunde 66:54-65

McPherron AC, Lawler AM, Lee SJ (1999) Regulation of anterior/ posterior patterning of the axial skeleton by growth/differentiation factor 11. Nat Genet 22:260-264
Nissen PH, Shukri NM, Agerholm JS, Fredholm M, Bendixen C (2001) Genetic mapping of spinal dysmyelination in cross-bred American Brown Swiss cattle to bovine Chromosome 11. Mamm Genome 12:180-182

Rieck GW, Schade W (1975) Arachnomelia (spider limbs), a new hereditary fatal malformation syndrome of cattle. Dtsch Tierärztl Wochenschr 82:342-347 (in German)

Singleton AC, Mitchell AL, Byers PH, Potter KA, Pace JM (2005) Bovine model of Marfan syndrome results from an amino acid change (c.3598G > A, p.E1200 K) in a calcium-binding epidermal growth factor-like domain of fibrillin-1. Hum Mutat $25: 348-352$

Testoni S, Gentile A (2004) Arachnomelia in four Italian Brown calves. Vet Rec 155:372

Thiele H, Nürnberg P (2005) HaploPainter: a tool for drawing pedigrees with complex haplotypes. Bioinformatics 21:17301732

Wigginton JE, Abecasis GR (2005) PEDSTATS: descriptive statistics, graphics, and quality assessment for gene mapping data. Bioinformatics 21:3445-3447 